\title{
PENGARUH TEKNIK SNOWBALL THROWING TERHADAP HASIL BELAJAR IPS POKOK BAHASAN PERMASALAHAN SOSIAL
}

\author{
Achmad Denny Ludfi, Muhtadi Irvan, Chumi Zahroul F. \\ Universitas Negeri Jember \\ chumizf@gmail.com
}

\begin{abstract}
Abstrak
Snowball throwing merupakan salah satu pembelajaran aktif (active learning) yang dalam pelaksanaannya banyak melibatkan siswa. Teknik snowball throwing, secara harfiah dalam kamus bahasa Indonesia snowball berarti bola salju sedangkan throwing berati melempar. Dalam artian yang sesungguhnya gumpalan kertas yg seperti bola dan di dalam nya berisi pertanyaan yang dibuat oleh orang lain teman ataupun guru. Bisa dikatakan bahwa snowball throwing merupakan modifikasi teknik bertanya menitik beratkan pada kemampuan membuat pertanyaan yang dikemas dalam sebuah permainan menarik yaitu saling melemparkan bola salju yang berisi pertanyaan kepada sesama teman. Tujuan untuk mengetahui pengaruh penerapan teknik snowball throwing terhadap hasil belajar IPS pokok bahasan permasalahan sosial pada siswa kelas IV SDN Sumbersari 03 Jember semester genap tahun pelajaran 2015-2016. Jenis penelitian yang digunakan adalah penelitian eksperimental dengan pola pre- test post-test control group design. Pengumpulan data menggunakan metode tes yang berupa tes obyektif pada pre-test dan post-test. Subyek penelitian yaitu siswa kelas IV yang terdiri dari kelas IVA dan kelas IVB SDN Sumbersari 03 Jember. Metode pengumpulan data yang digunakan adalah metode tes. Skor tes siswa berupa nilai hasil pre-test dan post-test yang dianalisis dengan uji-t menggunakan program SPSS versi 14.00 . Hasil analisis dengan rumus uji-t diperoleh $t_{\text {hitung }}=6,484$ dengan keefektifan relative sebesar $88,34 \%$. Hasil perhitungan uji-t di konsultasikan dengan $\mathrm{t}$-tabel pada $d b=64$, taraf signifikansi $5 \%$, sehingga diperoleh nilai $t$-tabel $=1,998$; dapat diketahui bahwa t-hitung $>t$-tabel $(6,484>1,998)$, sehingga dapat disimpulkan bahwa ada pengaruh teknik snowball throwing terhadap hasil belajar siswa kelas IV pokok bahasan masalah sosial di SDN Sumbersari 03 Jember tahun pembelajaran 2015/2016.
\end{abstract}

Kata kunci : teknik snowball throwing, hasil belajar, penelitian eksperimental.

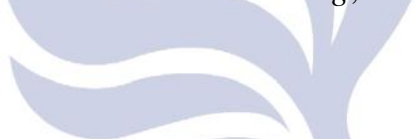

\section{Abstract}

Snowball throwing is one of active learning which in practice involves many students. Technigne snowball throwing, Indonesian dictionary means to throw snowballs. In a real sense, it means that crumpled paper ball and contains lists of questions made by pears or teachers. It could be said that the snowball throwing is a modification of the technique focuses the ability to ask a question that is packaged in an exciting game that is hurling snowballs containing questions to peers . The purpose of reseash is to determine the effect of applying snowball throwing technique to the learning outcomes of IPS subject on social issues to the fourth grade students of SDN 03 Jember Sumbersari second semester of school year 2015-2016. This type of research is experimental research with pre-test pattern posttest control group design. The data usid the test method in the form of objective tests on pre-test and post-test. The research subjects are students of class IV which consists of class IVA and IVB grade SDN 03 Sumbersari Jember. Test scores of students the pre- test and post-test were analyzed by t-test collection SPSS version 14.00. The results of the analysis of the $t$-test formula was $t=6.484$ with relative effectiveness of $88.34 \%$. The results of the t-test calculation consultion t-table on $\mathrm{db}=64,5 \%$ significance level, in order to obtain t-table value $=1.998$; it can be seen that $t$ count $>t$-table $(6.484>1.998)$, so that it can be concluded that there is was effect snowball throwing technique of the learning outcomes of fourth grade students in the subject of social problems SDN Sumbersari 03 Jember learning year 2015/2016.

Keywords : snowball throwing technique, learning outcomes, the experimental research.

\section{PENDAHULUAN}

Pendidikan ilmu pengetahuan sosial (IPS) dijenjang sekolah dasar perlu adanya pembaharuan karena pada kenyataan di lapangan selama ini masih banyak proses pembelajaran yang masih bersifat konvensional, tidak terlihat adanya kreativitas dan inovasi dalam pembelajaran, jauh dari pembelajaran yang modern sesuai dengan tuntutan jaman dan lingkungan sekitar dimana siswa berada. Menurut Sumaatmadja (2007: 1.10) untuk merealisasikan tujuan dari pendidikan IPS, proses mengajar dan membelajarkannya, tidak hanya terbatas pada aspek-aspek pengetahuan (kognitif) dan keterampilan (psikomotorik) saja, melainkan meliputi 
juga aspek sikap (afektif) dalam menghayati serta menyadari kehidupan yang penuh dengan masalah, tantangan, hambatan dan persaingan ini. Melalui pembelajaran IPS juga diharapkan fungsi dari IPS sebagai suatu pendidikan di sekolah dasar dapat tercapai.

Salah satu mata pelajaran di sekolah dasar yang dapat membantu siswa untuk dapat menyesuaikan diri dengan lingkungan dan menemukan solusi untuk menyelesaikan setiap permasalahan sosial secara baik adalah Ilmu Pengetahuan Sosial. Tujuan utama IPS adalah untuk membentuk siswa menjadi warga negara yang baik, untuk mewujudkan tujun tersebut, maka pembelajaran IPS sangat perlu mengembangkan kemampuan berpikir kritis siswa agar peka terhadap masalah-masalah sosial yang terjadi di masyarakat, tujuan tersebut sesuai dengan tujuan pembelajaran IPS yang termaktub dalam kurikulum 2006 (Depdiknas, 2006) materi ilmu pengetahuan sosial (IPS) bersifat deklaratif (hafalan) dan juga karena sebagian besar siswa tidak tertarik pada materi yang berwawasan lingkungan sosial masyarakat. Persoalan itu bisa terjadi karena pada kenyataannya dalam menyampaian materi guru hanya menggunakan metode ceramah, tanya jawab, dan diskusi, kurang divariasi dengan metode yang lain sehingga tidak melibatkan siswa secara aktif dan kritis dalam berfikir tentang materi yg disampaikan oleh guru (Sanjaya, 2008). Meskipun metode ceramah dan diskusi telah diterapkan yang mengharuskan siswanya untuk aktif, namun pada kenyataannya dari hasil observasi di kelas IV SDN Sumbersari 03 Jember semester genap tahun pelajaran 2015-2016 pada pokok bahasan masalah-masalah sosial yang dilakukan metode-metode tersebut belum dapat berjalan secara optimal (Lutfi, 2015). Masih terdapat beberapa siswa yang kurang terfokus pada materi saat pembelajaran sedang berlangsung. Siswa merasa bosan dan akibatnya mereka mengobrol sendiri, menganggu teman yang lain, dan ramai tidak memperhatikan materi yang guru sampaikan. Masalah yang diberikan pada siswa dalam pembelajaran IPS pada umumnya adalah masalah-masalah sosial yang ada dalam masyarakat. Siswa dengan bimbingan guru dituntut harus mampu menemukan solusi yang tepat dari permasalahan tersebut.

Berdasarkan tuntutan tersebut, guru yang professional hendaknya mampu merancang pembelajaran yang dapat meningkatkan hasil belajar siswa. Untuk itu diperlukan penerapan teknik pembelajaran yang tepat sesuai dengan materi, tujuan pembelajaran, karakteristik siswa serta sarana dan prasarana. Teknik pembelajaran yang sesuai dengan materi dan tujuan pembelajaran dapat membuat proses pembelajaran menjadi efektif. Efektivitas proses pembelajaran dapat dilihat dari aktivitas pembelajaran dan hasil belajar (Sanjaya, 2008).

Peran guru sangat penting pada penerapan teknik pembelajaran guru merupakan profesi yang memiliki peran bagi siswa. Guru juga berperan dalam mengelola kegiatan belajar-mengajar, dapat juga berfungsi sebagai fasilitator, motivator, demonstrator, dan evaluator (Sanjaya, 2008).
Salah satu fungsi guru sebagai pengelola pembelajaran harus mampu memilih metode, media pembelajaran yang sesuai karakteristik siswa dan materi yang di ajarkan, sehingga tujuan pembelajaran dapat tercapai secara optimal. Diharapkan dengan adanya keterampilan dalam memilih metode serta media yang dimiliki oleh guru inilah, siswa dapat aktif dalam kegiatan proses belajar-mengajar sampaikan di depan kelas, hal itu akan berdampak pada hasil belajar siswa tidak optimal/rendah.

Data dokumen tes hasil belajar menunjukkan masih banyak siswa yang belum memenuhi KKM. Hal ini dapat terlihat pada data lampiran hasil ujian akhir semester gasal kelas IV tahun pelajaran 2015/2016 menunjukkan bahwa kelas IVA dari 33 siswa sebesar 45,45\% (15 siswa) masih berada di bawah nilai KKM dan 54,54\% (18 siswa) sudah memenuhi nilai KKM, sedangkan kelas IVB dari 33 siswa sebesar 30,30 \% (10 siswa) masih berada di bawah nilai KKM dan 69,69 \% (23 siswa) sudah memenuhi nilai KKM.

Berdasarkan permasalahan diatas harus segera dicarikan solusi, salah satunya dengan penerapan teknik snowball throwing. Tujuan penelitian ini untuk mengetahui pengaruh penerapan teknik snowball throwing terhadap hasil belajar siswa kelas IVA Sumbersari 03 Jember. Menurut Bayor (dalam Hamdayana 2014:158) snowball throwing merupakan salah satu model pembelajaran aktif (active learning) yang dalam pelaksanaan nya banyak melibatkan siswa.

Teknik snowball throwing, secara harfiah dalam kamus bahasa Indonesia snowball berarti bola salju sedangkan throwing berati melempar. Dalam artian yang sesungguhnya gumpalan kertas yg seperti bola dan di dalam nya berisi pertanyaan yang dibuat oleh orang lain teman ataupun guru.

Melalui penggunaan teknik pembelajaran snowball throwing ini diharapkan siswa menjadi lebih termotivasi untuk mengikuti proses pembelajaran dan untuk menciptakan pembelajaran yang menyenangkan dan bermakna bagi siswa serta diharapkan dapat berpengaruh positif terhadap hasil belajar siswa.

Beberapa penelitian serupa telah dilakukan oleh beberapa peneliti (Kontes, 2012) membuktikan bahwa terdapat perbedaan hasil belajar yang signifikan, hal ini dibuktikan dari hasil belajar siswa diperoleh dari rata-rata nilai post-test, yaitu pada siswa kelas eksperimen yang menerapkan metode snowball throwing sebesar 90,84 sedangkan kelas kontrol yang menerapkan metode ceramah sebesar 85,31. Jadi dapat disimpulkan bahwa terdapat perbedaan hasil belajar antara siswa yang pembelajarannya menerapkan metode snowball throwing dengan siswa yang pembelajarannya menerapkan metode ceramah. Penelitian lain dengan desain pre-test post-test control group design dilakukan oleh (Woronitalia, 2011). menunjukkan bahwa teknik snowball throwing berpengaruh terhadap hasil belajar siswa. Hasil belajar yang signifikan antara kelompok siswa yang dibelajarkan dengan teknik snowball throwing dengan kelompok siswa yang dibelajarkan dengan model konvensional. 
Dari uraian di atas, peneliti ingin meneliti dengan judul "Pengaruh teknik snowball throwing terhadap hasil belajar IPS pokok bahasan permasalahan sosial pada siswa kelas IV SDN Sumbesari 03 Jember semester genap tahun pelajaran 2015-2016"

\section{METODE}

Jenis penelitian yang digunakan dalam penelitian ini adalah penelitian eksperimen. Penelitian eksperimen (Masyhud, 2014:136) merupakan penelitian yang dimaksudkan untuk mengetahui ada tidak nya pengaruh atau dampak dari suatu perlakuan (treatment) terhadap perubahan suatu kondisi atau keadaan tertentu.

Desain penelitian ini menggunakan desain pre-test post-test control group design (Masyhud, 2014:140) bertujuan untuk meneliti pengaruh murni dari suatu perlakuan dengan cara membentuk dua kelompok yang berimbang, dan kemudian menentukan kelompok eksperimental dan kelompok kontrol. Kedua kelompok sama-sama diberikan test awal (pretest), untuk mengukur dan memastikan kondisi awal masing masing kelompok. Langkah selanjutnya kelompok eksperimen diberikan perlakuan (treatment), sedangkan kelompok kontrol tidak diberi perlakuan, setelah selesai perlakuan kedua kelompok baik eksperimental maupun kontrol di test lagi (posttest) dengan alat ukur yang sama, yaitu alat ukur yang digunakan dalam pretest.

Responden penelitian dalam penelitian ini adalah kesuluruhan siswa kelas IV SDN Sumbersari Jember. Jumlah siswa kelas IVA sebanyak 33 siswa, sedangkan kelas IVB sebanyak 33 siswa. Penentuan responden menggunakan metode populasi yaitu dengan mengambil seluruh subjek siswa kelas IVA dan IVB. Menurut Arikunto (2006:325) rumus untuk menghitung uji homogenitas sebagai berikut:

$$
t o=\sqrt{M K d} \begin{array}{ll}
M_{1}-M_{2} \\
1+1 \\
n_{1} \quad n_{2}
\end{array}
$$

Gambar 1. Rumus uji t (Arikunto 2006:325)

Adapun ketentetuan analisis hasil $t$ observasi dapat dijelaskan sebagai berikut.

1) Jika $t_{o} \geq t_{\text {tabel }}$ dengan taraf signifikansi $5 \%$, maka $H_{0}$ ditolak sehingga tidak menunjukkan perbedaan mean yang signifikan.

2) Jika $t_{o}<t_{\text {tabel }}$ dengan taraf signifikansi 5\%, maka $H_{0}$ diterima sehingga menunjukkan perbedaan mean yang signifikan.

Teknik pengumpulan data menggunkan pre-test dan post-test. Sebelum soal tes tersebut diberikan kepada siswa dilkukan uji coba terlebih dahul untuk uji validitas, uji reabilitas, daya pembeda dan tingkat kesulitan. Instrumen soal yang akan digunakan untuk pre-test dan post-test sebanyak 34 item soal. Setelah mendapatkan hasil dari uji validitas intrumen ada 4 item soal dinyatakan tidak valid, selanjutnya melakukan uji reliabilitas pada 30 item soal. Dalam uji reabilitas penelitian ini, menggunakan metode uji "belah-dua" (Split-half), dengan metode belah-dua atau split-half (atas-bawah) dimana skor bagian belahan atas (dianggap sebagai variabel $\mathrm{X}$ ) dan skor bagian belahan bawah (dianggap sebagai variabel $\mathrm{Y}$ ) yang dikorelasikan menggunakan rumus Product moment . Korelasi tersebut dihitung menggunakan SPSS versi 14.0, perhitungan tersebut diperoleh hasil 0,757. Hasil korelasi tersebut kemudian diolah kembali dengan rumus SpearmanBrown sebesar 0,86 sehingga menunjukkan bahwa instrumen memiliki realibilitas dalam kategori tinggi sehingga layak digunakan untuk mengukur variabel penelitian.

Selain uji validitas dan uji realibiltas instrumen penelitian berupa tes harus memenuhi persyaratan daya pembeda (descrimination power) dan tingkat kesulitan (level of difficulties). Daya pembeda butir tes ditentukan dengan cara menghitung perbedaan persentase antara jawaban betul dari peserta tes kelompok pandai dan kelompok rendah.

Menurut Masyhud (2014:262) perhitungan daya pembeda butir soal tes menggunakan rumus sebagai berikut.

$$
\mathrm{IDP}=\frac{\sum J K T-\sum J K R}{\left(\frac{N T+N R}{2}\right)}
$$

Gambar 2. Rumus Indeks Daya Pembeda Tes (Masyhud, 2014:262)

Suatu soal dianggap memenuhi persyaratan jika memiliki indeks daya pembeda (IDP) atau minimal 0,20. Setelah menghitung indeks daya pembeda dilanjutkan dengan penghitungan indeks tingkat kesulitan butir tes. Adapun rumus untuk penghitungan indeks tingkat kesulitan tersebut adalah sebagai berikut.

$$
\mathrm{IKES}=\frac{\sum J K T+\sum J K R}{N T+N R}
$$

Gambar 3. Rumus Indeks Kesulitan Tes (Masyhud, 2014:263)

Analisis data yang digunakan dalam penelitian ini adalah teknik analisis statistik t-test sampel terpisah. Tujuan analisis data adalah untuk mengetahui ada tidaknya pengaruh teknik snowball throwing dihitung dengan rumus $t$-test sebagai berikut.

$$
\begin{aligned}
& t=\frac{M_{2}-M_{1}}{\sqrt{\frac{\sum x_{1}{ }^{2}+\sum x_{2}{ }^{2}}{N(N-1)}}} \\
& \text { Gambar 4. Rumus t-test } \\
& \text { (Masyhud, 2014:319) }
\end{aligned}
$$


Hipotesis dan ketentuan uji hipotesis dijelaskan sebagai berikut :

a. Hipotesis

$\mathrm{H}_{0}: \mu 1 \leq \mu 2$

$\mathrm{H}_{\mathrm{a}}: \mu 1>\mu 2$

Keterangan :

$\mathrm{H}_{0}=$ tidak ada pengaruh dari penerapan teknik snowball trowing terhadap hasil belajar siswa kelas IV pada mata pelajaran IPS Pokok Bahasan permasalahan sosial

$\mathrm{H}_{\mathrm{a}}=$ ada pengaruh dari penerapan teknik snowball trowing terhadap hasil belajar siswa kelas IV pada mata pelajaran IPS Pokok Bahasan permasalahan sosial

$\mu 1=$ rata-rata dari selisih nilai skor post-test dengan pretest kelompok eksperimen.

$\mu 2=$ rata-rata dari selisih nilai skor post-test dengan pretest kelompok kontrol.

b. Ketentuan uji hipotesis

untuk menguji $t_{\text {test }}$ dengan membandingkan $t_{\text {table }}$ pada taraf signifikan 5\% melalui ketentuan sebagai berikut:

a. harga $t_{\text {te }}$ st $\geq t_{\text {t a ble }}$ maka hipotesis nihil $\left(H_{0}\right)$ ditolak dan hipotesis alternatif $\left(H_{a}\right)$ diterima;

harga $t_{\text {te } s t}<t_{\text {t a ble }}$ maka hipotesis nihil $\left(H_{0}\right)$ diterima dan hipotesis alternatif $\left(H_{a}\right)$ ditolak.

\section{PEMBAHASAN}

Subyek pada penelitian ini berjumlah 66 siswa yang terdiri dari 2 kelas yaitu kelas IVA dan kelas IVB di SDN Sumbersari 03 Jember tahun ajaran 2015/2016. Kegiatan ini dilaksanakan di SDN Sumbersari 03 Jember pada tanggal 30 Januari 2016 sampai dengan 2 Februari 2016 Pada penelitian ini kelas IVA berjumlah 33 siswa sebagai kelas eksperimen yang mendapatkan pembelajaran dengan teknik snowball throwing dan kelas IVB yang berjumlah 33 siswa sebagai kelas kontrol yang mendapatkan pembelajaran dengan menggunakan metode ceramah dengan media gambar. Materi pokok yang dikaji dalam penelitian ini adalah permasalah sosial. Sebelum dilaksanakan proses belajar mengajar, dilakukan uji homogenitas. Data penelitian uji homogenitas yang dianalisa adalah nilai UAS untuk menentukan kelas yang akan dijadikan sebagai kelas eksperimen dan kelas kontrol melalui uji homogenitas.

Tabel. 1. Ringkasan Uji Homogenitas

Kelas Eksperimen Kelas Kontrol

Jumlah $\left(\sum\right)$

(IVA) (IVB)

\begin{tabular}{|c|c|c|c|}
\hline $\mathrm{N}_{\mathrm{K}}$ & 33 & 33 & 66 \\
\hline$\sum X_{K}$ & 2241 & 2269 & 4510 \\
\hline$\sum X^{2}{ }_{K}$ & 160485 & 163917 & 324402 \\
\hline$M_{K}$ & 67.91 & 68.76 & - \\
\hline
\end{tabular}

Dari hasil uji t di atas, dapat diperoleh hasil $t_{\text {hitung }}$ sebesar 0,217 Hasil tersebut kemudian dikonsultasikan dengan $t_{\text {tabel }}=1,998$. Dari hasil tersebut dapat diketahui bahwa hasil $t_{\text {hitung }}<t_{\text {tabel }}(0,217<1,998)$ sehingga keadaan kedua kelas sebelum diadakan penelitian adalah homogen., selanjutnya dilakukan pengundian untuk menentukan kelas eksperimen dan kelas kontrol. Hasil pengundian diperoleh bahwa kelas IVA kelas eksperimen dan kelas IVB sebagai kelas kontrol.

Data dalam penelitian ini diperoleh dari hasil penghitungan nilai pre-test dan post-test kelas eksperimen dan kontrol yang didapat selama penelitian ini dapat dilihat pada Tabel berikut.

Tabel. 2. Ringkasan perbandingan nilai siswa

\begin{tabular}{lcc}
\hline \multirow{2}{*}{ Keterangan } & \multicolumn{2}{c}{ Kelompok Penelitian } \\
\cline { 2 - 3 } & Kelas Eksperimen & Kelas Kontrol \\
\hline N jumlah siswa & 33 & 33 \\
\hline$\sum$ nilai pre-test & 1378 & 1543 \\
\hline & \multicolumn{2}{c}{ Kelompok Penelitian } \\
\cline { 2 - 3 } Keterangan & Kelas Eksperimen & Kelas Kontrol \\
\hline$\sum$ nilai post-test & & 1970 \\
siswa & 2362 & \\
\hline Rata-rata nilai & & 46.76 \\
pre test siswa & 41.76 & 59.7 \\
\hline Rata-rata nilai & & \\
post test siswa & 71.58 & \\
\hline
\end{tabular}

Selanjutnya dianalisis untuk pengujian hipotesis, analisis data statistik dalam penelitian ini dilakukan dengan menggunakan uji t. Dari hasil uji t di atas, dapat diperoleh hasil $t_{\text {hitung }}$ sebesar 6,484. Hasil tersebut kemudian dikonsultasikan dengan $t_{\text {tabel }}=1,998$. Dari hasil tersebut dapat diketahui bahwa hasil $t_{\text {hitung }}>\mathrm{t}_{\text {tabel }}(6,484>$ 1,998).

Hasil penghitungan uji statistik independent test menunjukkan harga $t_{\text {hitung }}=6,484$. Hasil $t$ hitung tersebut kemudian dikonsultasikan dengan $t_{\text {tabel }}$ pada taraf signifikansi $5 \%$ dengan nilai $d b=64$ mempunyai $\mathrm{t}_{\text {hitung }}=$ 1,998. Berdasarkan perhitungan tersebut dapat diketahui bahwa $t_{\text {hitung }}>t_{\text {tabel }}(6,484>1,998)$ sehingga hipotesis nihil ditolak dan hipotesis alternatif diterima. Dari hasil tersebut disimpulkan bahwa ada pengaruh dari teknik snowball throwing terhadap hasil belajar pokok bahasan masalah sosial pada siswa kelas IV di SDN Sumbersari 03 Jember, atau dengan kata lain kelompok siswa yang diajar dengan menggunakan teknik snowball throwing hasil belajarnya lebih baik dari pada kelompok siswa yang diajar tanpa menggunakan teknik snowball throwing.

Kemudian untuk mengetahui keefektifan relative (ER) teknik snowball throwing dapat dihitung dengan menggunakan snowball throwing dapat dihitung dengan 
menggunakan data rata-rata nilai pre-test dan post-test pada kelas kontrol dan kelas eksperimen dengan menggunakan rumus ER. Hasil perhitungan rumus ER diperoleh hasil 88,34\%, dibandingkan dengan metode konvesional tanpa menggunakan teknik snowball throwing pada hasil belajar IPS di SDN Sumbersari 03 Jember, dapat disimpulkan bahwa teknik snowball throwing menunjukkan lebih efektif sebesar 88,34\%.

Penelitian yang dilakukan dapat membuktikan bahwa teknik snowball throwing berpengaruh terhadap hasil belajar IPS di SDN Sumbersari 03 Jember. Hasil penelitian ini sesuai dengan pendapat Woolfolk (2009) yang mengatakan bahwa teknik snowball throwing sesuai dengan tingkat perkembangan dan karakteristik siswa dan penerapan teknik ini telah memberikan pengaruh yang positif dan terbukti efektif untuk membantu siswa dalam memahami materi. Pembelajaran dengan teknik snowball throwing juga sangat membantu peserta didik dalam membangun pengetahuanya karena melalui teknik snowball throwing guru menciptakan bentuk pembelajaran yang melibatkan siswa secara langsung dan aktif. Sesuai dengan apa yang dikemukan Hamdayama (2014:157) bahwa pembelajaran dengan snowball throwing menggunakan tiga penerapan pembelajaran : pengetahuan di bangun sedikit demi sedikit yang hasilnya diperluas melalui konteks yang terbatas melalui pengalaman nyata (constructivism), pengatahuan dan keterampilan yang diperoleh siswa diharapkan bukan hasil mengingat seperangkat fakta-fakta, tetapi hasil dari menemukan sendiri (inquiry), pengetahuan yang dimiliki seseorang, selalu bermula dari "bertanya" (questioning) sehingga kegiatan pembelajaran tidak hanya pasif mendengarkan materi yang disampaikan guru tetapi penggunaan teknik snowball throwing pada materi tentang masalah sosial dapat sangat membantu siswa dalam memahami masalah sosial sehingga siswa mampu memecahkan sendiri masalah sosial yang sering kali dijumpai dilingkungannya dengan saling melemparkan pertanyaan untuk berani menemukan jawaban dan menjawab berbagai pertanyaan tentang masalah sosial.

Pelaksanaan pembelajaran dengan teknik snowball throwing dimana siswa lebih aktif dalam pembelajaran yang berbentuk kelompok. Setiap kelompok membuat pertanyaan yang tertulis di॰ kertas, kemudian kertas tersebut dibentuk seperti bola dan dilempar pada kelompok yang lain untuk memberikan jawaban. Kondisi ini akan memunculkan suatu motivasi yang tumbuh dengan sendirinya dari peserta didik untuk berdiskusi dan menjawab pertanyaan yang diberikan oleh kelompok yang lain serta tidak merasa bosan mengikuti proses pembelajaran. Hal ini ditunjukkan dengan tanggapan peserta didik yang memberikan tanggapan baik dan sangat antusias untuk mengikuti pembelajaran IPS. Adanya suatu motivasi internal pada peserta didik dalam mengikuti pembelajaran maka akan berdampak pada hasil belajar siswa (Huda, 2013).

\section{PENUTUP}

\section{Simpulan}

Berdasarkan hasil penelitian dan pembahasan, dapat disimpulkan bahwa ada pengaruh teknik snowball throwing terhadap hasil belajar siswa kelas IV pokok bahasan masalah sosial di SDN Sumbersari 03 Jember tahun pembelajaran 2015/2016. Hal ini dapat dilihat pada hasil uji-t diperoleh 6,484 sedangkan $\boldsymbol{t}_{\text {tabel }}$ sebesar 1,998 $t_{\text {hitung }}>t_{\text {tabel }}$, sehingga $\boldsymbol{H}_{\boldsymbol{0}}$ ditolak dan $\boldsymbol{H}_{\boldsymbol{a}}$ diterima, yaitu ada pengaruh teknik snowball throwing terhadap hasil belajar siswa kelas IV pokok bahasan masalah sosial di SDN Sumbersari 03 Jember. Selain dilakukan penghitungan $t_{\text {hitung, }}$, dilakukan juga penghitungan keefektifan relatif teknik snowball throwing dibandingkan dengan metode konvensional. Hasil penghitungan keefektifan relatif (ER) snowball trowing menunjukkan lebih efektif sekitar $88,34 \%$ bila dibandingkan dengan kelompok yang diberikan pembelajaran tanpa menggunakan tehnik snowball trowing.

\section{Saran}

Berdasarkan hasil pembahasan dan kesimpulan, maka saran yang dapat diberikan oleh peneliti antara lain:

\section{1) Bagi guru}

Diharapkan dapat memakai teknik snowball throwing sebagai teknik alternatif dalam mengajar di sekolah sehingga dapat meningkatkan hasil belajar siswa.

2) Bagi pihak sekolah

Diharapkan dapat mendukung penggunaan teknik snowball throwing sebagai salah satu teknik yang dapat mendukung serta meningkatkan kualitas pendidikan pihak sekolah

3) Bagi peneliti

Diharapkan dapat menjadikan wawasan dan pengalaman dalam merumuskan masalah sampai melakukan penelitian sehingga dapat mengetahui proses penelitian dengan baik.

4) Bagi peneliti lain Hasil penelitian ini diharapkan dapat dijadikan sumber rujukan untuk mengembangkan penelitian sejenis

\section{DAFTAR PUSTAKA}

Arikunto, S. 2006. Prosedur Penelitian Suatu Pendekatan Praktik. Cetakan XIII. Jakarta: PT Rineka Cipta.

Depdiknas. 2006. Standar Kompetensi dan Kompetensi Dasar Mata Pelajaran IPS Sekolah Dasar dan Madrasah Ibtidaiyah. Jakarta: Depdiknas.

Hamdayama, J. 2014. Model dan Metode Pembelajaran Aktif. Bogor: PT. Ghalia Indonesia.

Huda, M. 2013. Model-model Pengajaran dan Pembelajaran. Yogyakarta: Pustaka Pelajar. 
Kontesa. 2012. Pengaruh Teknik Snowball Throwing terhadap Aktivitas dan Hasil Belajar Siswa. Skripsi tidak diterbitkan. Jember: PGSD Fakultas Keguruan dan Ilmu Pendidikan UNEJ.

Lutfi. 2015. Pengaruh Teknik Snowball Throwing terhadap Aktivitas dan Hasil Belajar Siswa. Skripsi tidak diterbitkan. Jember: PGSD Fakultas Keguruan dan Ilmu Pendidikan UNEJ.

Masyhud, S. 2014. Metode Penelitian Pendidikan. Jember: Lembaga Pengembangan Manajemen dan Profesi Kependidikan.

Sanjaya, W. 2008. Perencanaan dan Desain Sistem Pembelajaran. Jakarta: Kencana Renada Media Group.

Sumaatmadja, N 2007. Konsep Dasar IPS. Jakarta: UT.

Woolfok, A.E., dkk. 2009. Educational Psychology Active Learning. Edisi Bahasa Indonesia. Terjemah Helly Prayitno S. Yogyakarta: Pustaka Pelajar.

Woronitalia. 2011. Perbedaan Hasil Belajar Siswa antara Pembelajaran Konvesional dan Teknik Snowball Throwing. Skripsi tidak diterbitkan. Jember: PGSD Fakultas Keguruan dan Ilmu Pendidikan UNEJ.

Zahroul, R. dan Mardiati. 2011. Kajian IPS SD. Jember: Universitas Jember.

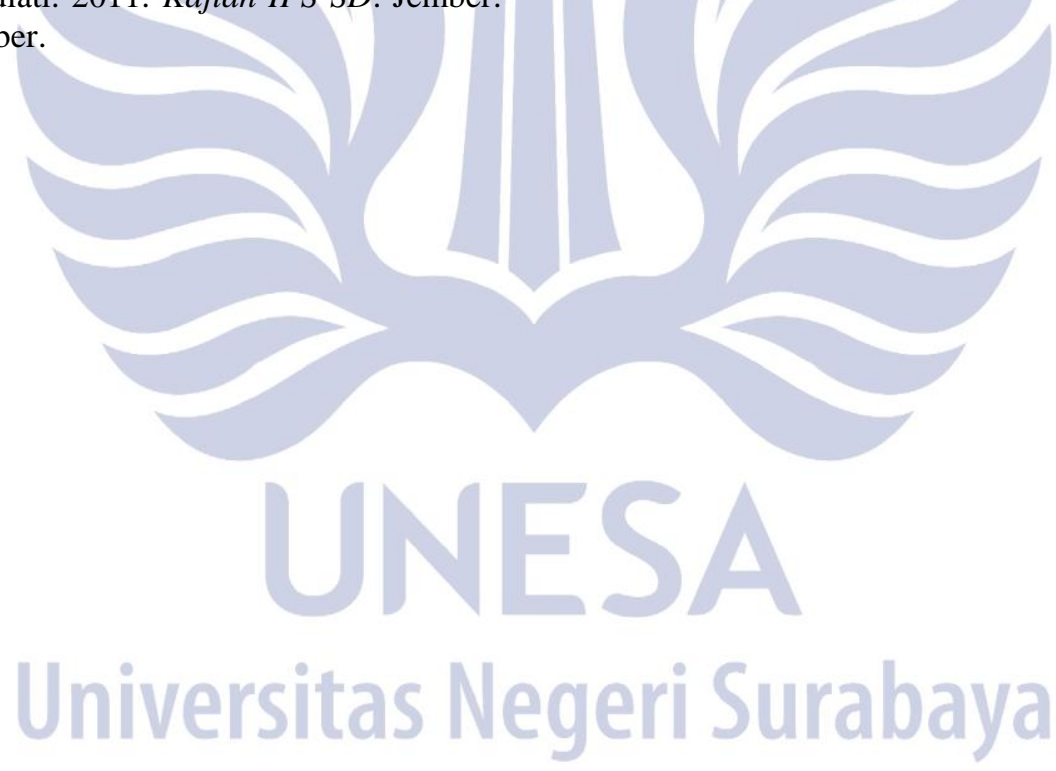

